\title{
ソルダ・インジェクション法による 高密度基板用バンプの作製
}

\section{塚 田 裕*}

\author{
High Density Carrier Bump Build by "Solder Injection" Method
}

Yutaka TSUKADA*

Key Words : Flip Chip Attach, Surface Laminar Circuit, Carrier Bump, Solder Injection

高密度のロジックチップを低コストのエポキシ系基板に実装するために, 共晶のはんだバン プを基板側端子にンルダ・インジェクション装置により作製する。この装置の原理とプロセス， 実際の適用について述べる。

\section{1.はじめに}

半導体チップのフリップチップ実装は, 他の実装方式 に比較して多くの優位性を持っている。アレイ状にジョ イントが配置できるので入出力端子の密度が高いこと, ジョイントが小さく寄生容量・インダクタンスが小さい ことによるすぐれた電気特性, 多数のチップを一度に装 着することが可能である生産性の高さなどである。しか しながら，そのジョイントの寿命は基本的にチップと基 板の材料の熱膨張係数の差に依存していた。それ故，熱 膨張係数の低いセラミック，一般的にはアルミナが基板 の材料に使用されてきた。さらに熱膨張係数の差による 応力を回避するため, 鉛の比深が高く塑性変形しやすい 高融点はんだがジョイントの材料として使用されてい る1”。これまで信頼性向上に対する開発は，基板材料に 熱胈張係数の低いるのを使用することであり，エポキシ のような低コストの材料についてはFCA (Flip Chip Attach）技術の出現まで目を向けられていなかった。 FCA は,フリップチップ実装の基板にエポキシをベー

*日本アイビーェム绦 野洲研究所（干520-23 滋賀県野洲郡野 洲町市三宅 800)

Yasu Lab., IBM Japan (800, Ichimiyake, Yasu-cho, Yasu-gun, Shiga 520-23)
スとする材料を使用し，その信頼性を確立したものであ る。FCA 実装では，熱膨張係数の差がアルミナを使用 した場合の 2 倍以上になるにすかかわらず、ジョイント の寿命をアルミナに実装する通常のフリップチップ実装 の数倍以上に伸ばすことに成功した。FCA 実装には二 つの技術的なポイントがある。一つは，大きな熱膨張係 数の差で生じる応力による疲労破壊からジョイントを保 護するため, チップの搭載後チップと基板の間のスペー スをエポキシ樹脂で封止する。すう一つは，エポキシの ようにセラミックに比較して耐熱性の低い材料にチップ を接合するために, 共晶はんだによりジョイントを形成 することである。従来のセラミック基板に使用している 高融点はんだは $350^{\circ} \mathrm{C}$ 以でリフローする必要があるの でエポキシのような材料は使えないが，FCAではチッ プ側の高融点はんだバンプを溶かさず，基板に形成した 共晶はんだのバンプを溶加すことによりチップ側の高融 点はんだとジョイントを形成する。そのためチップの接 合を通常の部品実装と同じ $200^{\circ} \mathrm{C}$ 程度の温度で行うこと ができる゙っ。图 1 はSurface Laminar Circuit(SLC)*1

*1 SLC(Surface Laminar Circuit)：ビルドアップ法を用いた プリント配線板で, 感光性エポキシの絶縁層に形成した微 小径のフォトビアホールにより, 通常の 2 倍以上の配線密 度を持つ。

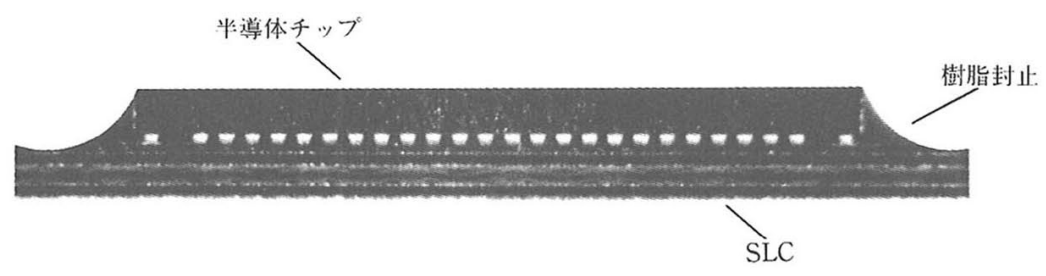

图 1 SLC/FCA 実装の断面 


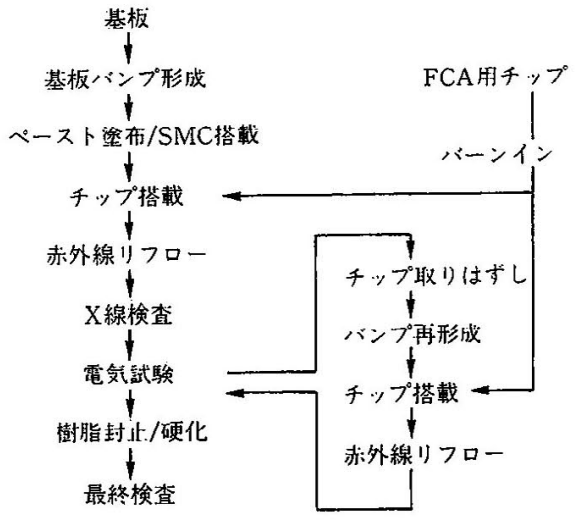

图 2 FCA 工程ステップ

基板に高密度のロジックチップを FCA 実装した断面で ある。

\section{FCA工程}

図 2 にFCAの工程ステップを示す。FCA工程は 4 個のセクタに分けることができる。基板側バンプ作製／ チップ接合・電気試験・樹脂封止である。半導休チップ はウェーファのレベルでテストされ, バーンインの必要 なものはSLCデックバーンイン*2工程, 必要のないも のはそのまま FCA工程に入る。SLC基板は，実装の最 初の工程であるソルダ・インジェクションで共晶はんだ バンプを FCA 用端子に形成する。チップはこの SLC 上のバンプにチップのバンプを光学装置により位置合わ せした後,フラックスをつけて基板上に置かれる。PGA

*2 SLCデックパーンイン: SLC基板をバーンイン用基板とし て使用し，FCA工程を利用してチップを仮付けし，バーン インノテストの後取り外して品賀の保証されたベアチップ を造る方法。
(Pin Grid Array), SMC (Surface Mount Component）等は基板の端子にはんだペーストをつけた後 置かれる。はんだのリフロー工程は一般の赤外線炬でり

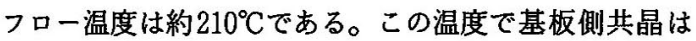
んだバンプが溶けてチップ側のバンプとジョイントを形 成する。図 3 は完成した FCA ショィントの断面写真で ある。チップ側のバリヤメタルは直径 $150 \mu \mathrm{m}$, 基板側 は $75 \times 100 \mu \mathrm{m}$ の矩形端子で, ジョイントの高さは 100 $\mu \mathrm{m}$ である。

ジョイントの中で黒く見える部分が高融点はんだで, 白い部分が共晶はんだである。高融点はんだと共晶はん だの境界は,わずかに拡散しているが高融点はんだは溶 けていない。リフローによるチップの接合後, X線検查 および電気試験を行う。ジョイントは共晶はんだが高融 点はんだに濡れることにより形成されるので，はんだと はんだの接合なので需れが悪くて接合不良になることは 極めて少ない。チップ自体が電気的に不良の場合におい ても，赤外線ランプ等で共晶のはんだを溶かし，容易に 取り除くことができる。その後, 基板側のバンプをソル ダ・インジェクションで形成し直し, 新しいチップを置 き再度リフローする。電気試験でチップの動作を確認し た後にチップと基板の間隙をエポキシ樹脂で封止する。 樹脂は毛細管現象により間隙を埋め, 熱硬化させること により完全に封止される。樹脂封止を完了した後にチッ プの不良が発見されるケースは非常に少ないが, その場 合にはチップと樹脂の一部を機械的に削り，露出したバ ンプ部分に新たな共晶はんだバンプを形成し, 最初と同 じステップにてチップの接合を行う。

\section{3. 基板側バンプの体榬}

FCAのジョイントの信頼性はチップ側の端子である BLM (Ball Limiting Metallergy) ${ }^{* 3}$ の寸法, 基板

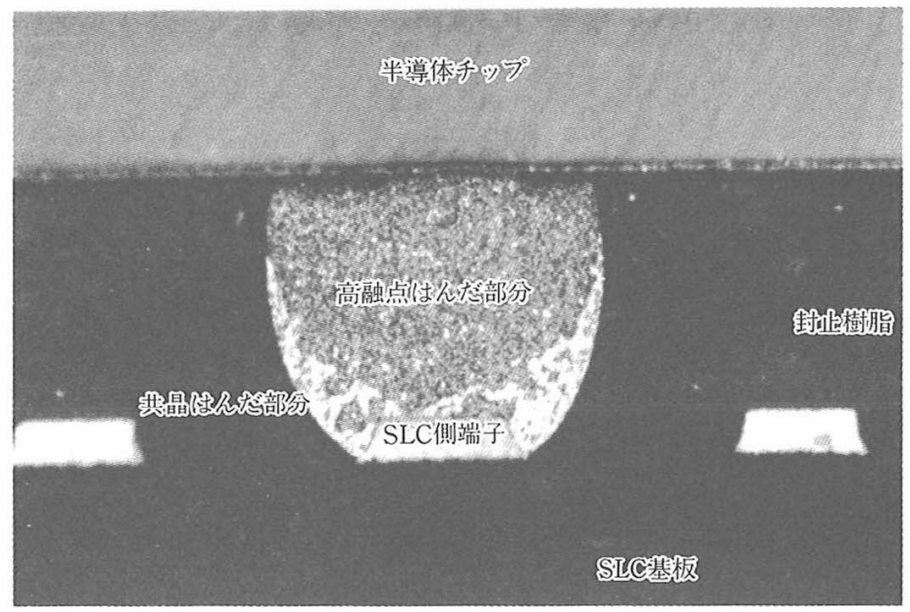

図3 FCA ジョイントの断面 




図4 はんだバンプ体積のコントロール

側の端子の寸法及びジョイントの高さによる。BLM と 基板側端子の寸法が決まっている場合には, ジョイント の高さははんだの体積に依存する。はんだの総体積は高 融点はんだと共晶はんだの体積の和であるので，それぞ れの工程におけるはんだ量のコントロールがジョイント のプロファイルを決定するので重要である。図 4 ははん だ体積のコントロールの概念を，チップバンプから FCA ジョイントの完成に至るまで工程の流れに沿って表した あのである。チップには半導体工程での蒸着により鉛の 多いはんだをつける（図中(1)）。バーンイン工程におい て, チップは共晶はんだを持った SLCで造られたバー ンインキャリア（2) に仮付けされ（3)，バーンイン と電気試験終了後に共晶はんだを溶かしてキャリアより 取り外される。そのためチップのバンプには共晶のはん だが追加される (4))。バーンインキャリアに用意され ているはんだは，バーンインを行う時に必要な電気的な 接合を満たす最低限の体積なので，チップバンプに僅か の共晶はんだが移るだけである。バーンインキャリアの はんだはチップを取った後（(5)，ソルダ・インジェク ションで再度形成され（6)，キャリアは30回以上リサ イクルし低コストのバーンインを実現している。

FCA工程においては，基板側の共晶はんだバンプは バーンインキャリアより多めの量が必要である。製品の 信頼性の要求に合うジョイントが形成されるように十分 な量が必要である (8)。体積の最低量は, FCAのジョ イントが形成されたときに共晶はんだの部分でネックダ ウンを起こさないように設定する。共晶はんだの体積が 少なすぎる場合には，チップバンプの表面に拡散してし まい, システムのオン／オフの熱サイクルよる疲労破壊 に耐える強度を保つのに充分なジョイントが形成できな

*3 BLM(Ball Limiting Metallurgy): 半導体チップのアルミ 配線端子にクローム/銅を蒝着したバリアメタル部分。さ らに鈶/スズを蒸着した後に溶かしてチップバンプを形成 するが，BLMのサイズによりバンプの形状が決まる。


図 5 ソルダ・インジェクションのコンセプト

い。体積の最大量はジョイントが形成された後に，樹脂 封止の際ジョイント間を樹脂が流れるのを妨げないよう に設定される。体積が多すぎてジョイント間の間隙が狭 すぎると，封止樹脂中のフィラーがひっかかり樹脂の流 れを妨げてボイドを生じる。ソルダ・インジェクション 工程はこれらのそれぞれの段階におけるはんだ体積を要 求にしたがって付けることができる。

\section{4.ソルダ・インジェクション工程}

昨今，ロジックチップの入出力端子数は非常に多くなっ てきている。チップ側のバンプとジョイントを形成する 基板側のバンプのピッチは小さくパターンは複雑である。 このようなバンプを形成する方法はいくつか考えられる が, 工程に課せられた要求を満たすことは難しい。はん だペーストは簡便であるが体積のコントロールが充分で きない。はんだめっきは多くの工程ステップが必要でコ ストがかかり，まためっきしたはんだの組成比や体積の 分布を一定に保っこと， SMC と FCA 端子のはんだ必 要量の違いをコントロールすることが難しい。はんだ付 けのコテにより端子にはんだを与えるような方法では, 銅に対するはんだの濡れ角 $23.5^{\circ}$ により制限されて必要 
量をつけることができない。

ソルダ・インジェクションのコンセプトを工程ステッ プで図 5 に示す。インジェクション装置のへッドには下 部にマスクがついているはんだのリザバーがあり (a), そのマスクには基板の FCA 接合部の端子に合ったパター ンの孔が開いている。リザバーに圧力が加えられると (b)のようにはんだはマスクの孔から出て基板の端子に 接触し, 溶けたはんだの柱がマスクの孔と基板の端子の 間に形成される。そしてリザバーの圧力は，マスクと基 板の間に流れ出ようとするはんだの柱の表面張力の総和 とバランスする。リザバーの圧力を除くと(c) のように はんだの柱はマスクの孔からリザバーの中に戻る。最後 にはんだの柱はつづみ状になりくびれた部分で切れ，上 部はリザバーの中に戻り下部は基板に(d)のように残る。 リザバーに与えられる圧力ははんだを小径の孔から押し 出すのに充分でかっマスクと基板の間に流れ出してしま わないようにコントロールされる。

この圧力はラプラスの式から式(1)として与えられる。

$$
\begin{aligned}
\frac{4 \gamma_{1}}{D_{1}}<\Delta P<2 \gamma_{1}\left\{\frac{1}{S}+\frac{1}{\left(D_{1}+S\right)}\right\} \\
\Delta P: \text { リザバーの压力 } \\
\gamma_{1}: \text { 溶けたはんだの表面張力 } \\
D_{1}: \text { マスクの孔径 } \\
S: \text { マスクと基板の間の距離 }
\end{aligned}
$$

最低圧力はマスクの孔においてはんだボールを孔径と 同じ直径にするすのとして与えられる。最大圧力はマス クと基板の間に流れ出そうとするはんだの曲率が，それ らの距離と等しくなる時として与えられる。この圧力を 越すとはんだはマスクと基板の間に流れ出してしまう。

\section{5.はんだ体積の推定}

基板に残されたはんだの体積はつづみ状のはんだが分 離するポイントの位置による。分離する直前はんだの形 状は図 5 (c)のようになる。くびれた部分の寸法が限界 を越すとはんだは二つに分離する。基板端子に残された はんだの体積はラプラスの式により正確な計算にで求め られるが，この計算は非常に複雑であり，かつ溶けたは んだの詳細な物性が必要である。このような複雑な条件 による計算の代わりに，はんだの柱に対する寸法により 簡便に推定する方法として図 5 (c) に点線で示す三角錐 に近似して計算し, 補正項を与えてはんだ体積を求める こととした。

三角錐近似においてはんだの体積は式 (2)で与えられ る。

$$
\begin{gathered}
V=\frac{\pi}{12} \cdot H \cdot \frac{D_{2}{ }^{3}}{\left(D_{1}+D_{2}\right)} \\
V: \text { バンプの体積 }
\end{gathered}
$$

$H$ : 基板表面からマスク表面までの距離

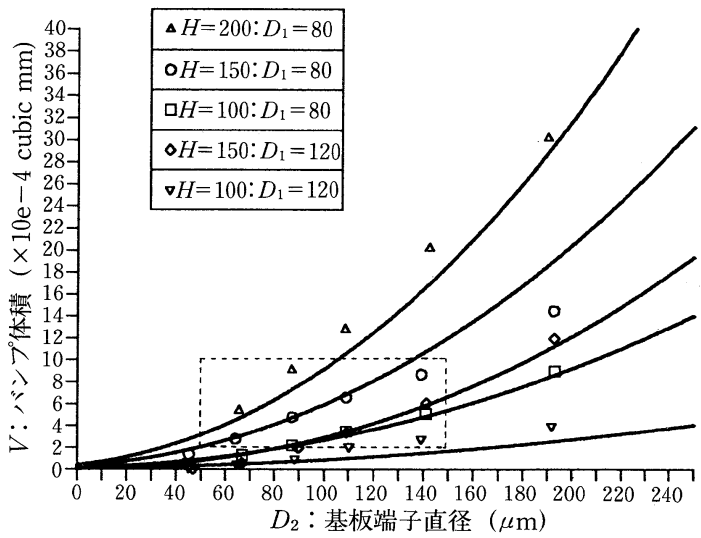

図 6 はんだバンプ体積の実験值と計算値

\section{$D_{1}:$ マスク孔径 \\ $D_{2}$ : 基板端子の直径}

図 6 はマスク孔径 $\left(D_{1}\right)$, 基板端子の直径 $\left(D_{2}\right)$, マス クの高さ $(H)$ による実験により測定されたバンプの体積 をプロットしたすのと，近似式を実験值をもとにして補 正して得られた近似曲線を示した。このときのパラメー 夕は以下の組合せである。実験值はそれぞれの組合せに おいて 9 個の測定の平均である。

$H=100 \mu \mathrm{m}$ で $D_{1}=80,120 \mu \mathrm{m}, D_{2}=40 \sim 200 \mu \mathrm{m}$

$H=150 \mu \mathrm{m}$ で $D_{1}$ と $D_{2}$ は $H=100 \mu \mathrm{m}$ と同じ

$H=200 \mu \mathrm{m}$ で $D_{1}=80 \mu \mathrm{m}$ と $D_{2}=40 \sim 200 \mu \mathrm{m}$

近似式は計算を単純化するために式(2)を $\alpha, \beta, \gamma$ を使用して変形し導いた。

$$
\begin{aligned}
& \alpha=\frac{D_{2}}{D_{1}}, \quad \beta=\frac{H}{D_{1}}, \quad \gamma=\frac{V}{D_{1}{ }^{3}} \text { としたとき } \\
& \gamma=\frac{\pi}{12} \cdot \frac{\alpha^{3} \beta}{(1+\alpha)}
\end{aligned}
$$

$\alpha ， \beta$ にオフセット值を与えて式(4)を導く。

$$
\gamma=A \cdot \frac{\pi}{12} \cdot \frac{(\alpha+B)^{3}(\beta+C)}{\{1+(\alpha+B)}
$$

$A, B, C=$ 定数

式(4)が最も実験結果の測定値に合うように $A, B, C$ の 值を決定し式(5)が得られる。

$$
\gamma=1.99 \cdot \frac{\pi}{12} \cdot \frac{(\alpha+0.5)^{3}(\beta-0.74)}{\{1+(\alpha+0.5)\}}
$$

すなわち；

$$
V=1.99 \cdot \frac{\pi}{12} \cdot \frac{\left(0.5 D_{1}+D_{2}\right)^{3}\left(H-0.74 D_{1}\right)}{\left(1.5 D_{1}+D_{2}\right)}
$$

図は測定值に合わせて式(6)により与えられた近似線 を示しているが， $D_{1}$ に対し $D_{2}$ の大きい部分と $D_{2}$ が $40 \mu \mathrm{m}$ 以下の部分で近似線は測定值から外れており，そ の原因は実際の状態と近似との差と考えられるが今後の 解析によらねばならない。パラメータの領域によって以 
上のように近似が合わない部分があるが，図6において 点線で示されている実際に使用される領域については式 (6)は十分使用することができる。

\section{6. 装置とアプリケーション}

ソルダ・インジェクション装置はマスクを装着したリ ザバーを持つへッドと XYステージ，その間にマスク のホールパターンと基板の端子のアラインメントをとる 光学装置が出入りする。XY ステージの基板を取りつけ 光学装置を通してTVモニタに二重に写し出されたマス クのホールと基板の端子のアラインメントを取った後, 基板にフラックスを塗布してへッドを降ろしインジェク ションのシークエンスを行う。インジェクション後基板 は洗浄される。さらにンルダ・インジェクション装置を 用いてバンプのリワークを容易に行うことができる。チッ プを取り外した際，基板には少量のはんだが残されるが， その箇所に新しいチップを取りつけるにはバンプの再形 成を行う必要がある。新しく行う場合と同様に装置にか けてインジェクションを行うと、マスクから出たはんだ が基板に残されたはんだを溶かし吸収するので，どのよ うな量が残っていても再度一定量にリセットすることが できる。

このンルダ・インジェクションの優位性は, 大きなは んだ量を簡単な装置で与えることができることである。 ソルダ・インジェクションを行った SLC上の FCA 端 子の写真を図 7 に示す。この FCA に搭載されるチップ は $12.7 \mathrm{~mm}$ 角でバンプ数は 560 個，そのピッチは 225 $\mu \mathrm{m}$ で 5 列の干鳥状の配置となっている。マスクは FCA のバンプパターンによりそれぞれ必要であるが, パターンに一定のルールがあれば複数個の FCA に対し 共通のマスクを使用することができる。基板側にはんだ が濡れる端子がなければ, 孔から出たはんだは全量また リザバーに戻る。図 8 は基板バンプの電子顕微鏡写真で ある。これまで実行されたバンプの最大数は $12.7 \mathrm{~mm} の$

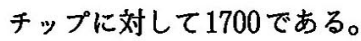

\section{7. まとめ}

(1) 高密度の FCA 実装に対して基板バンプを作製する ソルダ・インジェクション装置を開発した。 (2)バンプのはんだ体積はマスクの孔径，基板の端子径， およびマスクの高さにより容易にコントロールすること ができる。

(3) バンプの体積は三角錐分離の仮定式で推定すること

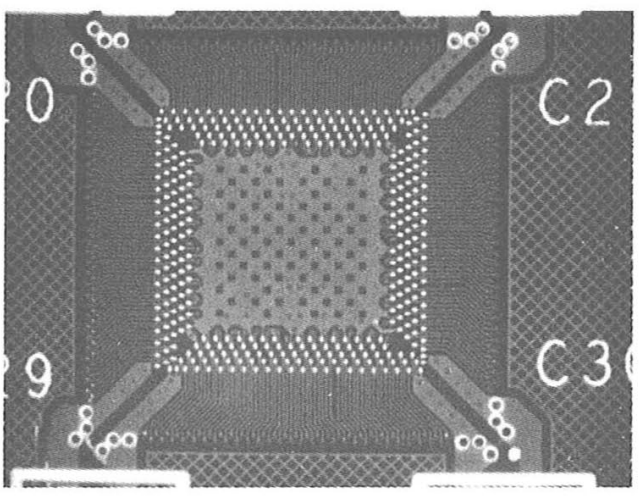

图7アプリケーション基板の FCA 搭載部分



図 8 基板バンプの電子䫓徽鏡写真

ができる。ただし，より精密な計算は，はんだ柱の分離 時の形状，条件を見つけることにより可能となる。

(4) 本プロセスはFCA 以外の他の高密度実装部品の端 子のはんだに対しても使用が可能である。

(5) 本装置は米国，日本，ヨーロッパに特許申請がなさ れている。

(1993-11-15 受理)

\section{文献}

1) K. C. Norris and A. H. Landsberg ; IBM Journal Research and Development, 13, (3), p.266 (1969)

2) Y. Tsukada, Y. Mashimoto, T. Nishio and N. Mii ; Proc. of ASME/JSME Joint Conf. on Electronic Packaging, Vol. 2, pp.827-835 (Sept. 1992)

3) Y. Tsukada and S. Tsuchida ; Proc. of Surface Mount International Conf. Vol. 1, pp.537-542 (Aug. 1992) 